\title{
Phosphorus (P) for Citrus Trees ${ }^{1}$
}

Mongi Zekri and Tom Obreza²

This publication is part of a series about understanding nutrient requirements for citrus trees. For the rest of the series, visit http://edis.ifas.ufl.edu/ topic_series_citrus_tree_nutrients.

To maintain a viable citrus industry, Florida growers must consistently and economically produce large, highquality fruit crops from year to year. Efficiently producing maximum yields of high-quality fruit is difficult without understanding soil and nutrient requirements of bearing citrus trees. Most Florida citrus is grown on soils inherently low in fertility with low cation exchange capacity (CEC) and low water-holding capacity, thus soils are unable to retain sufficient quantities of available plant nutrients against leaching caused by rainfall or excessive irrigation.

Seventeen elements are considered necessary for the growth of green plants: carbon $(\mathrm{C})$, hydrogen $(\mathrm{H})$, oxygen $(\mathrm{O})$, nitrogen $(\mathrm{N})$, phosphorus $(\mathrm{P})$, potassium $(\mathrm{K})$, magnesium $(\mathrm{Mg})$, calcium $(\mathrm{Ca})$, sulfur $(\mathrm{S})$, manganese $(\mathrm{Mn})$, zinc $(\mathrm{Zn})$, iron $(\mathrm{Fe})$, copper $(\mathrm{Cu})$, boron $(\mathrm{B})$, chlorine $(\mathrm{Cl})$, molybdenum (Mo), and nickel (Ni). Plants obtain $\mathrm{C}, \mathrm{H}$, and $\mathrm{O}$ from carbon dioxide and water. The remaining elements, called the "mineral nutrients," are obtained from the soil. Mineral nutrients are classified as macronutrients and micronutrients. The term "macronutrients" refers to those elements that plants require in large amounts (N, P, K, $\mathrm{Mg}, \mathrm{Ca}$, and S). The term "micronutrients" applies to plant nutrients that are essential to plants but are needed only in small amounts ( $\mathrm{Mn}, \mathrm{Zn}, \mathrm{Fe}, \mathrm{Cu}, \mathrm{B}, \mathrm{Cl}, \mathrm{Mo}$, and $\mathrm{Ni}$ ). This publication reviews the phosphorus $(\mathrm{P})$ requirements of citrus trees.

\section{Introduction}

Meeting the world's escalating food needs cannot be achieved without fertilizer input. Without fertilizer, the world would produce only about half as much food, and more forested and marginal lands would have to be put into production. Inorganic commercial fertilizer plays a critical role in the world's food security, and it is important from both yield and food quality perspectives. Intensifying production and increasing yield on limited arable land are clearly important to secure a sufficient food supply, and fertilizer plays a critical role in these goals.

Intensifying production is essential to meet the challenge of future food demands. However, this intensification must be done while minimizing environmental impacts. The $4 \mathrm{R}$ Nutrient Stewardship framework (i.e., right fertilizer source, right rate, right time, and right place) is therefore very important.

\section{Phosphorus Functions}

Phosphorus is present in all living tissue. It is particularly concentrated in younger plant parts, flowers, and seeds. Phosphorus is needed for photosynthesis, synthesis, and breakdown of carbohydrates, and the transfer of energy within the plant. It helps plants store and use energy from photosynthesis to form seeds, develop roots, speed maturity, and resist stress. Phosphorus is involved in nutrient uptake and translocation. It is a major part of the cytoplasm and the nucleus of cells, where it is involved in the organization of cells and the transfer of heredity characteristics.

1. This document is SL379, one of a series of the Department of Soil and Water Science, UF/IFAS Extension. A version of this article was previously published in Citrus Industry magazine. Original publication date: July 2013. Visit the EDIS website at http://edis.ifas.ufl.edu.

2. Mongi Zekri, multicounty citrus UF/IFAS Extension agent; and Tom Obreza, professor and interim associate dean for Extension; UF/IFAS Extension, Gainesville, FL 32611. 
Table 1. Effects of $P$ on citrus fruit quality

\begin{tabular}{|l|l|l|}
\hline \multicolumn{1}{|c|}{ Variable } & Juice Quality & Rating \\
\hline Juice Content & 0 \\
\hline Soluble Solids (SS) & 0 \\
\hline Acid (A) & - \\
\hline SS/A Ratio & + \\
\hline Juice Color & External Fruit Quality & 0 \\
\hline Solids/Box & 0 \\
\hline Solids/Acre & + \\
\hline Size & & 0 \\
\hline Weight & 0 \\
\hline Green Fruit & + \\
\hline Peel Thickness & - \\
\hline Increase (+), Decrease (-), No change (0) & \\
\hline
\end{tabular}

Phosphorus is also important for cell division and enlargement. Thus, plant growth is reduced when the $\mathrm{P}$ supply is too low.

Excess $\mathrm{P}$ can affect fruit quality in the following ways:

- Reduced acid concentration, which increases the TSS/ acid ratio

- Increased number of green fruit

- Reduced peel thickness

- Increased expression of wind scar

Phosphorus is listed on the fertilizer label as $\mathrm{P}_{2} \mathrm{O}_{5}$, where it is referred to as "available phosphoric acid." Phosphorus does not readily leach unless the soil is extremely sandy or low in organic matter. A citrus crop removes only approximately $2 \mathrm{lb}$. of $\mathrm{P}$ per 100 boxes of fruit. Most mature Florida citrus groves contain sufficient residual $\mathrm{P}$ accumulated from previous fertilizer applications, so regular P fertilizer applications are usually not necessary.

Some soils used for new citrus plantings are naturally low in P. These soils are commonly found in "sand-soaked" areas. In this situation, $\mathrm{P}$ fertilizer should be applied until a soil test $\mathrm{P}$ rating of medium to high is achieved. Phosphorus fertilizer should be applied each year in newly planted groves on previously non-fertilized soil until the groves begin to bear fruit. As the trees approach maturity, $P$ applications may be reduced or omitted. Diagnostic information from leaf and soil testing can help determine if $P$ fertilization is necessary.

\section{Phosphorus Deficiency}

Phosphorus deficiency is not common in Florida citrus groves. If it does occur, it is more difficult to diagnose than nitrogen $(\mathrm{N})$ deficiency or other nutrient element deficiencies. Growth is reduced when $\mathrm{P}$ supply is too low. Phosphorus is highly mobile in plants, so when it is deficient, it may move from old leaves to young leaves and other actively growing areas where energy is needed to form seeds and fruit.

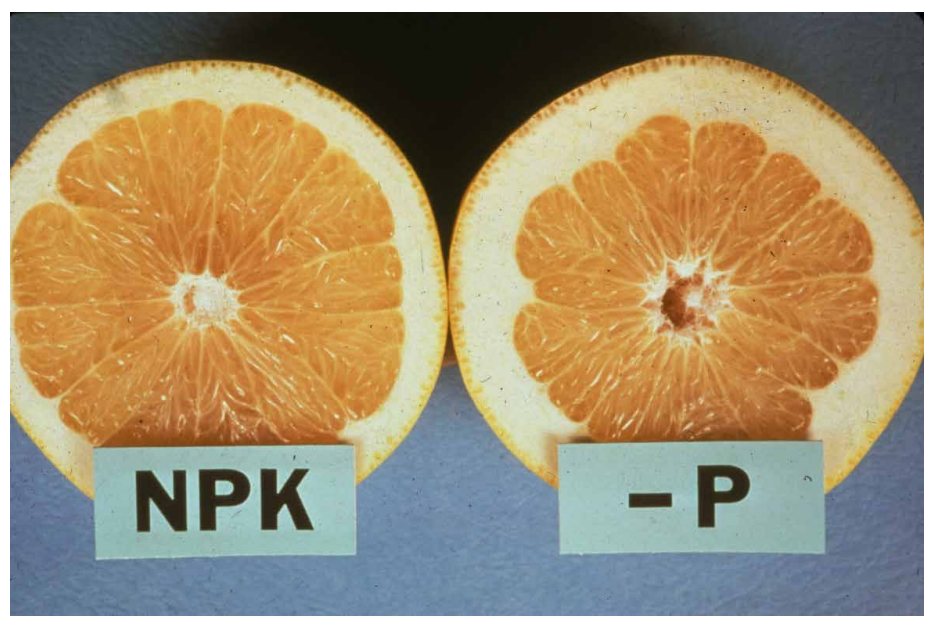

Figure 1. A thick rind and hollow core are both symptoms of $P$ deficiency in citrus trees.

Credits: Dr. R.C.J. Roo

Because P moves from older to younger tissue, deficiency symptoms appear first on older leaves, which lose their deep green color. Leaves are small and narrow, with a lusterless purplish or bronze discoloration. Some leaves later develop necrotic areas, and young leaves show reduced growth rate. Leaves shed prematurely, and fruit can drop 
before normal harvesting time. P deficiency symptoms are not strongly expressed on citrus foliage. Trees exhibit limited flower development with reduced fruit set and fruit yield. The fruit turns rough in texture with a coarse, thick rind and a hollow core (see Figure 1). The fruit has high acidity in proportion to total soluble solids. Thus, fruit maturity is delayed. Usually, roots are stunted and poorly branched.

The cause of $\mathrm{P}$ deficiency is a lack of available $\mathrm{P}$ in the soil. Phosphorus deficiency may occur because of leaching and erosion where soils are sandy and the climate is humid. Phosphorus may also react with clay, iron $(\mathrm{Fe})$, aluminum (Al) or calcium (Ca) in the soil and become less available and less mobile. In strongly acidic soils, such as those found in Brazil, $\mathrm{P}$ can become quickly unavailable through fixation or immobilization by Fe and Al. Phosphorus availability can also be reduced in calcareous soils through Ca fixation.

When P fertilizer is added to a calcareous soil, it undergoes a series of chemical reactions with $\mathrm{Ca}$. These reactions decrease $P$ solubility through a process called $P$ fixation. Consequently, long-term $\mathrm{P}$ availability to plants is controlled by the application rate of soluble $\mathrm{P}$ and the dissolution of fixed P. Applied P is available to replenish the soil solution for only a relatively short time before it converts to less soluble P forms. Phosphorus deficiency can be corrected by applying $\mathrm{P}$ fertilizer to the soil or foliage after confirming P deficiency using leaf and soil analysis.

Common solid sources of $\mathrm{P}$ applied to citrus groves include the following:

- Ordinary superphosphate

- Concentrated superphosphate

- Monoammonium phosphate (MAP)

- Diammonium phosphate (DAP)

The P source in both ordinary ("single" or "normal") and concentrated ("triple") superphosphate is mono-calcium phosphate, $\mathrm{Ca}\left(\mathrm{H}_{2} \mathrm{PO}_{4}\right)_{2}$. The major difference between these two fertilizers is that ordinary superphosphate contains gypsum (calcium sulfate) and concentrated superphosphate does not. If the fertilizer program calls for dry material, using superphosphates may have the following advantages: they are relatively inexpensive; they are appropriate for application to soil of any $\mathrm{pH}$ (especially alkaline soil); and they supply sulfur to plants.
Although MAP and DAP are two products that sound nearly the same, their reactions in the soil are very different. High acidity forms around a dissolving MAP granule, while high alkalinity forms around a dissolving DAP granule. Therefore, do not apply DAP to an alkaline soil because $\mathrm{P}$ becomes unavailable due to tie-up by $\mathrm{Ca}$ and $\mathrm{N}$ is lost to the atmosphere by volatilization.

The following P nutrient sources are used to manufacture true solutions:

- Ammonium polyphosphate

- Phosphoric acid

Ammonium polyphosphate may be applied to the soil with a boom or injection wheel, but it should not be injected into a microirrigation system. Ammonium polyphosphate is not an acidic material, but has a slightly acidic reaction in the soil. Phosphoric acid is usually added to liquid fertilizers for application to soil or injected into irrigation water. If phosphoric acid is injected into a microirrigation system connected to a high-calcium water source, the emitters may clog because the calcium phosphate can precipitate.

These P nutrient sources are applied in foliar sprays:

- Potassium phosphite

- Ammonium phosphite

- Phosphorous acid

Phosphorus fertilizers are generally supplied to plants as salts of phosphoric acid $\left(\mathrm{H}_{3} \mathrm{PO}_{4}\right)$. When phosphoric acid is neutralized by potassium hydroxide $(\mathrm{KOH})$, it forms potassium phosphate $\left(\mathrm{KH}_{2} \mathrm{PO}_{4}\right)$. However, if phosphorous acid $\left(\mathrm{H}_{3} \mathrm{PO}_{3}\right)$ is neutralized with $\mathrm{KOH}$, it forms potassium phosphite $\left(\mathrm{KH}_{2} \mathrm{PO}_{3}\right)$, also known as phosphite or phosphonate. While the phosphate form of $\mathrm{P}$ is not easily absorbed by citrus leaves, the phosphite form is readily absorbed. Phosphite has been shown to accelerate foliar uptake of potassium, calcium, magnesium, and most micronutrients. Because phosphite has one less oxygen molecule than phosphate, a higher degree of solubility and mobility is achieved in the plant. This unique characteristic permits plant foliage and/or roots to rapidly absorb phosphites, and these play a nutritive role in crops, including citrus trees. 
Table 2. Interpretation of soil analysis data for P (ppm) using the Mehlich 1 (double-acid) extractant

\begin{tabular}{|l|l|l|l|l|l|}
\hline & Very Low & Low & Medium & High & Very High \\
\hline Phosphorus & $<10$ & $10-15$ & $16-30$ & $31-60$ & $>60$ \\
\hline
\end{tabular}

Table 3. Guidelines for interpretation of orange tree leaf P (\%) analysis based on 4- to 6-month-old spring flush leaves from nonfruiting twigs

\begin{tabular}{|l|l|l|l|l|l|}
\hline & Deficient & Low & Optimum & High & Excessive \\
\hline Phosphorus & $<0.09$ & $0.09-0.11$ & $0.12-0.16$ & $0.17-0.30$ & $>0.30$ \\
\hline
\end{tabular}

Table 4. Recommendations for P fertilization of bearing citrus trees based on leaf tissue and soil tests (leaf and soil samples taken in July or August of each year). ${ }^{1}$

\begin{tabular}{|c|c|c|}
\hline If leaf tissue $P$ is... & ... and soil test $P$ is... & ...the recommendation for $P$ fertilization is: \\
\hline $\begin{array}{l}\text { Excessive } \\
\text { High }\end{array}$ & $\begin{array}{l}\text { Very High } \\
\text { High } \\
\text { Medium } \\
\text { Low } \\
\text { Very Low }\end{array}$ & \multirow[t]{2}{*}{$\begin{array}{l}\text { Do not apply P fertilizer to the soil for } 12 \text { months following } \\
\text { leaf and soil sampling, then sample again and re-evaluate. }\end{array}$} \\
\hline Optimum & $\begin{array}{l}\text { Very High } \\
\text { High } \\
\text { Medium }\end{array}$ & \\
\hline Optimum & $\begin{array}{l}\text { Low } \\
\text { Very Low }\end{array}$ & $\begin{array}{l}\text { Apply } 8 \mathrm{lb} . \mathrm{P}_{2} \mathrm{O}_{5} \text { /acre to the soil for every } 100 \text { boxes/acre of } \\
\text { fruit produced during the current year. Sample leaves and } \\
\text { soil again in } 12 \text { months and re-evaluate. }\end{array}$ \\
\hline Low & $\begin{array}{l}\text { Low } \\
\text { Very Low }\end{array}$ & $\begin{array}{l}\text { Apply } 12 \mathrm{lb} . \mathrm{P}_{2} \mathrm{O}_{5} \text { /acre to the soil for every } 100 \text { boxes/acre } \\
\text { of fruit produced during the current year. Sample leaves } \\
\text { and soil again in } 12 \text { months and re-evaluate. }\end{array}$ \\
\hline Deficient & $\begin{array}{l}\text { Low } \\
\text { Very Low }\end{array}$ & $\begin{array}{l}\text { Apply } 16 \mathrm{lb} . \mathrm{P}_{2} \mathrm{O}_{5} / \text { acre to the soil for every } 100 \text { boxes/acre } \\
\text { of fruit produced during the current year. Sample leaves } \\
\text { and soil again in } 12 \text { months and re-evaluate. }\end{array}$ \\
\hline
\end{tabular}

The optimum range of $\mathrm{P}$ in citrus leaves is $0.12 \%-0.16 \%$. Phosphorus is deficient if leaf $\mathrm{P}$ is less than $0.09 \%$. Appropriate $\mathrm{P}$ management is important not only for higher crop yield but also for environmental protection. Slowing soil erosion can significantly decrease particulate and dissolved forms of $\mathrm{P}$ loss. Before deciding to apply $\mathrm{P}$ fertilizer to citrus, test the soil and leaves for $\mathrm{P}$, and apply the results to Table 4 above.

\section{Conclusion}

Growers should be aware that the soil mineral fraction reacts quickly to remove dissolved $\mathrm{P}$ from solution. In order to maximize the availability of soil $\mathrm{P}$, soil $\mathrm{pH}$ should be monitored and maintained in the range of 6.0-6.5. An appropriate nutrient balance is necessary to achieve optimum plant nutrition. Balanced use of plant nutrients corrects nutrient deficiencies and toxicities, improves soil fertility, increases nutrient- and water-use efficiency, enhances crop yields and fruit quality, develops tree tolerance to pests, diseases, and other stresses, and improves environmental quality. 